sessed the mind; those of the hours of uneasy sleep seize and play with those forms in wilder fancies still. Sleeping or waking, we can remember but one man whose mind protested against the vision that haunted it. M. Delepierre, indeed, says that many of the early visionaries retracted - more or less of the first editions of their wondrous narratives ; but Mr. White, the Assessor of the Westminster Assembly, resisted the visions. Satan (on whose works he had been long meditating) one night came to the Assessor's bedside, as the latter had just lain down, seated himself, and looked at the astounded gentleman in a way to banish sleep for a month. The Assessor rubbed his eyes, muttered "This will never do," and then, gazing full in the face of the Prince of Darkness, quietly remarked, "I'll tell thee what it is. If thou hast nothing better to do, I hare! I am going to sleep." After this wholesome exercise of mind, the Assessor was never more troubled by visionary visitors. His story might well find place in a second edition of $\mathbf{M}$. Delepierre's collection of narratives. But among the many singularities of what we may well call this rare book is, that the anthor does not contemplate a second edition, and has printed only twenty.five copies of that which, as we may notice, is well illustrated, and which will doubtless meet fitting audience, though, it may be, few.-The Athenoum, June 30.

\title{
Mr. Carlyle on the Education of the Future.
}

I confess it seems to me there is in it a shadow of what will onc day be ; will and must, unless the world is to come to a conclusion that is alto. gether frightful : some kind of scheme of education analogous to that; presided orer by the wisest and most sacred men that can be got in the world, and watching from a distance: a training in practieality at every turn; no speech in it except speech that is to be followed by action, for that ought to be the rule as nearly as possible among men. Not very often or much, rarely rather, should a man speak at all, unless it is for the sake of something that is to be done; this spoken, let him go and do his part in it, and say no more about it.

I will only add that it is possible, - all this fine theorem of Goethe's, or something similar! Consider what we have already; and what 'difficulties' we have overcome. I should say there is nothing in the world you can conceive so difficult, primâ facie, as that of getting a set of men gathered together as soldiers. Rough, rude, ignorant, disobedient people; you gather them together, promise them a shilling a day; rank them up, give them very severe and sharp drill; and by bullying and drilling and compelling (the word drilling, if you go to the original, means 'beating,' 'steadily tormenting' to the due pitch), they do learn what it is necessary to learn; and there is your man in red coat, a trained soldier; piece of an animated machine incomparably the most potent in this world; a wonder of wonders to look at. He will go where bidden; obeys one man, will walk into the cannon's mouth for him; does punctually whatever is commanded by his general officer. And, I belicve, all manner of things of this kind could be accomplished, if there were the same attention bestowed. Very many things could be regimented, organised into this mute system ;-and perhaps in some of the mechanical, commercial, and manufacturing departments, some faint incipien. ces may be attempted before very long. For the saving of human la. bour, and the avoidance of human misery, the effects would be incalcu. able, were it set about and begun even in part. 
Alas, it is painful to think how very far away it all is, any real fulfil. ment of such things! For I need not hide from you, young gentlemen,and it is one of the last things I am going to tell you,-that you have got into a very troublous epoch of the world; and I don't think you will find your path in it to be smoother than ours has been, though you have many advantages which we had not. You have careers open to you, by public examinations and so on, which is a thing much to be approved of, and which we hope to see perfected more and more. All that was entirely unknown in my time, and you have many things to recognise as advantages. But you will find the ways of the world, I think, more anarchical than ever. Look where one will, revolution has come upon us. We have got into the age of revolutions. All kinds of things are coming to be subjected to fire, as it were : hotter and hotter blows the element round everything. Curious to see how, in Oxford and other places that used to seem as lying at anchor in the stream of time, regardless of all changes, they are getting into the highest humour of mutation, and all sorts of new ideas are afloat. It is evident that whatever is not inconsumable, made of asbestos, will have to be burnt, in this world. Nothing other will stand the heat it is getting exposed to.

And in saying that, I am but saying in other words that we are in an epoch of anarchy. Anarchy plus a constable! (Laughter.) There is nobody that picks one's pocket without some policeman being ready to take him up. (Renewed laughter.) But in every other point, man is becoming more and more the son, not of Cosmos, but of Chans. He is a disobedient, discontented, reckless, and altogether waste kind of object (tho commonplace man is, in these epochs); and the wiser kind of man,- the select few, of whom I hope you will be part,-has more and more to see to this, to look vigilantly forward; and will require to move with double wisdom. Will find, in short, that the crooked things he has got to pull straight in his own life all round him, wherever he may go, are manifold, and will task all his strength, however great it be.

But why should I complain of that either? For that is the thing a man is born to, in all epochs. He is born to expend every particle of strength that God Almighty has given him, in doing the work he finds he is fit for ; to stand up to it to the last breath of life, and do his best. We are called upon to do that; and the rerrard we all get,-which we are perfectly sure of if we have merited it,-is that we have got the work done, or at least that we have tried to do the work. For that is a great blessing in itself; and I should say, there is not very much more reward than that going in this world. If the man gets meat and clothes, what matters it whether he buy those necessaries with seven thousand a year, or with seven million, could that be, or with seventy pounds a year? He can get meat and clothes for that; and he will find intrinsically, if he is a wise man, wonderfully little real difference. (Laughter.)

On the whole, avoid what is called ambition; that is not a fine prin.ciple to go upon,-and it has in it all degrees of vrulgarity if that is a consideration. "Seekest thou great things, seek them not:" I warmly second that advice of the wisest of men. Don't be ambitious; don't too much need success; be loyal and modest. Cut down the proud towering thoughts that get into you, or see that they be pure as well as high. There is a nobler ambition than the gaining of all California would be, or the getting of all the suffrages that are on the Planet just now. (Loud and prolonged cheers.)

Finally, gentlemen, I have one advice to give you, which is practically of very great importance, though a very humble one. In the midst of your zeal and ardour, - for such, I foresee, will rise high enough, in spite 
of all the counsels to moderate it that I can give you,- - remember the care of health. I have no doubt you have among you young souls ardently bent to consider life cheap, for the purpose of getting forward in what they are aiming at of high; but you are to consider throughout, much more than is done at present, and what it would have been a very great thing for me if I had been able to consider, that health is a thing to be attended to continually; that you are to regard that as the very highest of all temporal things for you. (Applause.) There is no kind of achievement you could make in the world that is equal to perfect health. What to it are nuggets and millions? The French financier said, "Why, is there no sleep to be sold!" Sleep was not in the market at any quotation. (Laughter and applause.)

It is a curious thing, which I remarked long ago, and have often turned in my head, that the old word for ' holy' in the Teutonic languages, heilig, also means ' healthy.' Thus Heilbronn means indifferently ' holy-well,' or 'health-well.' We have, in the Scotch too, ' hale,' and its derivatives; and, I suppose, our English word 'whole' (with a ' $w$ '), all of one piece, without any hole in it, is the same word. I find that you could not get any better definition of what ' holy' really is than 'healthy.' Completely healthy; mens sana in corpore suno. (Applause.) A man all lucid, and in equilibrium. His intellect a clear mirror geometrically plane, brilliantly sensitive to all objects and impressions made on it, and imaging all things in their correct proportions; not twisted up into convex or concave, and distorting everything, so that he cannot see the truth of the matter without endless groping and manipulation: healthy, clear, and free, and discerning truly all round him. We never can attain that at all. In fact, the operations we have got into are destructive of it. You cannot, if you are going to do any decisive intellectual operation that will last a long while; if, for instance, - you are going to write a book,-you cannot manage it (at least, I never could) without getting decidedly made ill by it : and really one nevertheless must; if it is your business, you are obliged to follow out what you are at, and to do it, if even at the expense of health. Only remember, at all times, to get back as fast as possible out of it into health ; and regard that as the real equilibrium and centre of things. You should always look at the heilig, which means ' holy' as well as 'healthy.'

And that old etymology - what a lesson it is against certain gloomy, austere, ascetic people, who have gone about as if this world were all a dismal prison-house. It has indeed got all the ugly things in it which I have been alluding to; but there is an eternal sky over it; and the blessed sunshine, the green of prophetic spring, and rich harvests coming,-all this is in it, too. Piety does not mean that a man should make a sour face about things, and refuse to enjoy wisely what his Maker has given. Neither do you find it to have been so with the best sort, - with old Knox, in particular. No; if you look into Knox you will find a beautiful Scotch humour in him, as well as the grimmest and sternest truth when necessary, and a great deal of laughter. We find really some of the sunniest glimpses of things come out of Knox that I have seen in any man; for instance, in his 'History of the Reforma. tion,- -which is a book I hope every one of you will read (Applause), a glorious old book.

On the whole, I would bid you stand up to your work, whatever it may be, and not be afraid of it; not in sorrows or contradictions to yield, but to push on towards the goal. And don't suppose that people are hostile to you or have you at ill-will, in the world. In general, you will rarely find anybody designedly doing you ill. You may feel often as if 
the whole world were obstructing you, setting itself against you: but you will find that to mean only, that the world is travelling in a different way from you, and, rushing on its own path, heedlessly treads on you. That is mostly all : to you no specific ill-will;-only each has an extremely good-will to himself, which he has a right to have, and is rush. ing on towards his object. Keep out of literature, I should say also, as a general rule (Laughter), - though that is by-the-by. If you find many people who are hard and indifferent to you, in a world which you consider to be inhospitable and cruel, as often indeed happens to a tenderhearted, striving young creature, you will also find there are noble hearts who will look kindly on you; and their help will be precious to you beyond price. You will get good and evil as you go on, and have the success that has been appointed you.

I will wind up with a small bit of verse which is from Goethe also, and has often gone through my mind. To me, it has something of a modern psalm in it, in some measure. It is deep as the foundations, deep and high, and it is true and clear :- no clearer man, or nobler and grander intellect, has lived in the world, I believe, sinco Shakspeare left it. This is what the poet sings; - a kind of road-melody or marchingmusic of mankind:

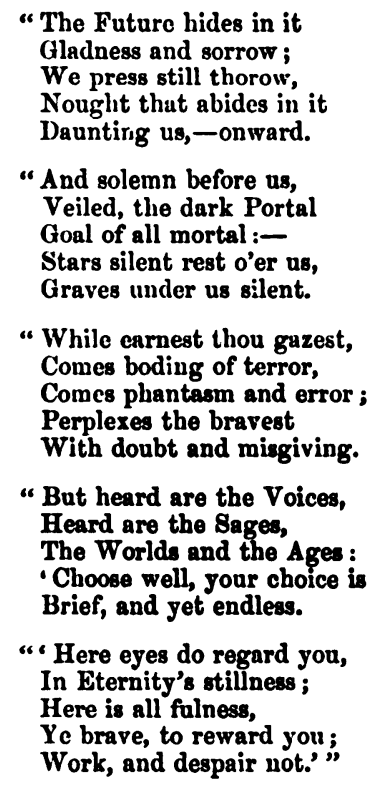

Work, and despair not: Wir heissen euch hoffen, "We bid you be of hope!"-let that be my last word. Gentlemen, I thank you for your great patience in hearing me; and, with many most kind wishes; say Adieu for this time.-Inaugural Address at Edinburgh, 1866. 